\title{
AVATAR AS SYMPTOM: HOLLYWOOD MYTHOLOGICAL NARRATIVE AND CRISIS
}

\author{
Fernando simão vugman ${ }^{1}$
}

\begin{abstract}
The present essay analyzes Avatar (2009) by director James Cameron in the context of the great American mythological narratives. With a focus on the performance of the myth of the Frontier and of the Manifest Destiny, in addition to the American Dream, that film's script, mise-en-scène and characters are discussed as a rupture with Hollywood and mythological conventions. Such a rupture of the conventions of the myth is understood as a symptom of an important crisis currently experienced by American society, thus reflecting the need to rethink the present of the country, as well as its future alternatives.
\end{abstract}

Keywords: American mythology. American crisis. Film and technology. Hollywood. Avatar.

By now much has been written and said about the technological contribution of James Cameron's Avatar (2009) to film making. Its huge success at the box office has arguably encouraged many studios and filmmakers to use 3D technology, though a number of such films had already been made. ${ }^{2}$ By now, much of such technological developments have been adopted and even improved by a number of other filmmakers and studios. In fact, the concern with using (and developing) state of the art technology in the making of Cameron's film shows some ideological and cultural implications that shall be analyzed and discussed along with the film's script, which brings forward some significant cultural issues for American society, as it's relation to Nature (about which the film presents an openly environmentally correct story); and the waging of wars, more specifically to more recent military campaigns (about which the film displays an apparently critical stance).

The discussion to follow will analyze how the film's explicit discourse on Nature and war falls into contradiction. Avatar will also be approached as a mythological narrative $^{3}$ in the line of those films centered on the Myth of the Frontier and the Manifest Destiny, portraying the encounter of the "civilized" white and the Indians, by means of the conventions of the western to favor the indigenous cultures. In such films the white hero learns to respect and eventually adopts the natives' culture. ${ }^{4}$ And here

\footnotetext{
1 Professor Dr. da Pós-graduação em Ciências da Linguagem e do Curso de Cinema e Realização Audiovisual (UNISUL). Editor da revista digital Crítica Cultural. Autor de A casa sem fim (ficção) e Pesadelos (pós)modernos e ficção (teoria e crítica). Tradutor.

${ }^{2}$ A very short list by well-known filmmakers would include films as Cameron's own Ghosts of the Abyss (2003); Robert Zemeckis's The Polar Express (2004) and Beowulf (2007); John Lasseter's Toy Story (1995), Toy Story 2 (1999) and Toy Story 3 (2010, Lee Unkrich); Martin Scorsese's Hugo (2011); Steven Spielberg's The Adventures of Tintin (2011); and Tim Burton's Alice in Wonderland (2011).

${ }^{3}$ For a more detailed discussion on Hollywood as the privileged factory of contemporary American mythology, see VUGMAN, Fernando Simão. The Gangster in Film and Literature: Study of a Modern American Monster. Florianópolis, 2001. 271 f. Dissertation (PhD in Letters) - Center of Communication and Expression, Universidade Federal de Santa Catarina.

${ }^{4}$ A well-known precedent is Dances with Wolves (1990), by Kevin Costner. In that film the hero, Lt. John Dunbar (Kevin Costner) asks to be assigned to a remote western Civil War outpost were he befriends
} 
Avatar breaks an important convention, allowing the hero to take an unprecedented step by not just adopting the Indians' way of life, but becoming their leader against "civilization." Now, according to historian Richard Slotkin a myth changes through time in order to encompass significant changes in the history of a given society, since it is the "problems that arise in the course of historical experience" $(1998, p$. 6) that myths come to explain. So here it will be investigated what current historical event is significant enough to justify the change in the myth in Avatar; in other words, that change in the myth is a symptom of what crisis in America?

The first myth to be analyzed is that which states that a never-ending technoscientific development will eventually conquer all of humanity's problems, a myth originating in the project of Enlightenment, which believed that science and reason would ensure the control of Nature, ${ }^{5}$ the rational organization of society (capable of working efficiently, in contrast with Nature's chaotic violence), an hygienic society (defeating all diseases, another "natural" plague, while giving birth to the perfect body). About the Enlightenment project Marxist sociologist Jürgen Habermas (1985) claims that it is not a failed project, but only incomplete, still to be completed, while for French postmodern philosopher and theoretician Jean-François Lyotard $(1986,1993)$, the failure of such a project was definitely established with the advent of II World War and the Holocaust.

The brief reference above to the debate about those ideas that are at the root of what has come to be known as Modernity aims at calling attention to the significance of the myth of continuous technoscientific development for the organization of Western societies in general, but more specifically for molding American economy and culture. America's prowess in technoscientific development has been one of its foundations as the world's superpower in the twentieth century; a superiority in military technology, for sure, but also America's technological superiority in the industrial production of cultural goods, which together deliver a coherent narrative of the world that bears American dominant ideology. And Hollywood has arguably been the main tool to spread its values around the world and to conquer alien cultures. Some traits of American dominant ideology include not only the belief in those myths of modernity, but also some very national myths, as the Manifest Destiny ${ }^{6}$ and the Myth of the Frontier. ${ }^{7}$

In "Ideology, Genre, Auteur", Robin Wood lists the most frequent ideological elements in Hollywood films. The fourth component in his list is twofold: "Nature as

wolves and Indians, thus becoming a nuisance to the military. He eventually "goes native"; however, he does not become the leader of the tribe.

${ }^{5}$ Here "Nature" is written with a capital ' $N$ ' when reference is made to the human, i.e. cultural, concept and "nature" to refer to the natural environment itself, which is, after all, inaccessible to us.

${ }^{6}$ The myth of the Manifest Destiny, which has long justified American imperialism, originates from the encounter between Puritan settlers and the Indians. For Slotkin (1996; p 21), the "cultural anxieties and aspirations of the colonists found their most dramatic and symbolic portrayal in the accounts of the Indian wars." From that clash the colonists could "emphasize their Englishness (...); they could suggest their own superiority to the home English by exalting their heroism in battle (...) [and reaffirm] the holly zeal for English Christian expansion with which they preached to or shot at the savages."

${ }^{7}$ According to Slotkin (1996; p 5) the Myth of the Frontier comes from "the conception of America as a wide-open land of unlimited opportunity for the strong, ambitious, self-reliante individual to thrust his way to the top." 
agrarianism; the virgin land as Garden of Eden" (47), and "Nature as the wilderness, the Indians, on whose subjugation civilization is built" (47). Both views of Nature spring from the Myth of the Frontier, what Slotkin calls in The Fatal Environment "arguably the longest-lived of American myths, with origins in the colonial period and a powerful continuing presence in contemporary culture" (15). Slotkin claims that the

\begin{abstract}
ideological underpinnings [of the Myth of the Frontier] are those same 'laws' of capitalist competition, of supply and demand, of Social Darwinian 'survival of the fittest' as a rationale for social order, and of 'Manifest Destiny' that have been the building blocks of our dominant historiographical tradition and political ideology (1985, p. 15).
\end{abstract}

At the root of the Myth of the Frontier one finds the unresolved contradiction faced by the colonists of Nature as Eden and Nature as chaos. The former view was part of the hopes of the European colonists when leaving the Metropolis towards America, while the latter image included the "Puritans' sexual anxieties, reflected in their feeling that the Indians were lewd and sexually "unclean"” (SLOTKIN, 1973, p. 76).

Avatar deals with the same contradictions about Nature as Eden and as chaos, which has been translated in terms of military conquests and of the conquering of Nature. What is noteworthy is how Cameron attempts to solve these contradictions.

In the case of the military strategy for the conquering of Nature it is explicitly presented in the film as one of the main elements of tension in the plot. In fact, that is precisely one of the elements, which the fans of the film point as an example of Cameron's concern about contemporary social and political conflicts; the film's critical stand on the military, who are there to help in the exploitation of the planet and to ensure the profits for RDA, a private enterprise that stands for "international capital", and who ends up defeated, has been read as a reference to the invasion of Iraq, a war waged in order to allow American and allied oil companies to explore that country's mineral riches. There are, however, some problems with such an interpretation, when one gives a closer look at some internal contradictions in such a discourse.

The first contradiction can be observed in the victory of Nature -the whole planet, Pandora, unites to fight the human invaders in the final battle- over the technologicalmilitary paraphernalia of the "international capital". After all, the very conditions of existence of Cameron's film are his own and Hollywood's obsession with technological development as a goal in itself, as something good in itself, together with their immoderate pursuit of profit; the box office number are all records ${ }^{8}$, surpassing the previous box office champion, Titanic (1997), directed by the same James Cameron. How can such a film put forward a discourse for the abandonment of technology in the name of a return to Nature? ${ }^{9}$

\footnotetext{
8 According to Box Office Mojo, available at <http://boxofficemojo.com/movies/?id=avatar.htm $>$. Accessed on 04/09/2014.

9 In fact, Mr. Cameron seems much concerned about Nature when its domestication favors other countries, as in his protesting against Brazil's Belo Monte dam. However, he does not seem much concerned about the oil extraction in Alaska, just to mention an environmental issue closer to home.
} 
A second internal contradiction: in order to present his environmentally correct narrative, Cameron and his team revolutionized audiovisual technology so to project on the screen an incredibly beautiful and seductive Nature, while simultaneously reinforcing in the public a feeling of rejection of the "bad" technology. However, in the same move they replace the real nature (chaotic and violent, even for the peoples of the forest) with Nature as spectacle; a Nature that can only exist in the universe of digital images, and which surpasses, dismisses and erases nature itself (for more on the society of the spectacle see DEBORD, 1997). In other words, in order to stand for the natural environment, Cameron offers to the public a Nature that is only accessible by means of state of the art technology, displayed in movie theatres equipped with high technology, hygienic and, of course, a place one has to pay to be allowed. Mr. Cameron, of course, is facing an unsolvable contradiction: how can one speak in the name of nature without creating Nature? Nonetheless, in the case of Avatar such a contradiction renders the very erasure of nature; it renders the "naturalization," in the Barthesian sense, of artificial Nature.

It is also noteworthy how Avatar presents the old conflict between nature and civilization, an issue of global concern. An issue, in fact, that much before the appearance of the first global preservationist movements, American society already had to face dramatically and in a very particular way, and that would solve it, at the symbolic level, in a way that marked its culture until today.

As already mentioned, according to Slotkin (1996, 1998, 1998a), in the seventeenth century the Puritans had to face a grave problem: they had left England to America with the belief that they would find a natural world, paradise on Earth itself; there they would build a superior civilization, following the precepts of God, and from there they would disseminate their ways and values to the rest of the world (that still being America's justification for its imperialism, the already mentioned Manifest Destiny). However, when the Puritans arrived at the east coast what they found was nature with very different characteristics from what existed in Europe, inhospitable, and to make it worse, inhabited not by angels of the Lord, but by peoples with strange customs; for the Puritans, a primitive people.

In such a situation some consequences followed: first, the actual destruction of nature and of the native inhabitants, while they conquered the new territory. But that was a long historical process that would only acquire greater significance in the twentieth century. Another consequence came from the understanding by the colonizers that if on the one hand they could not identify with the native peoples of the land, on the other hand they would have to learn at least part of their ways if they were going to survive in that new landscape. Here one finds the origins of the American hero: an individual, a white man, who must learn and resort to the ways and values of a "primitive" people in order to establish and protect his own civilization (which hurts nature). In that process, he became a character from two worlds: not a savage, nor civilized. And that is the hero who is generated from the clash between the colonizer and Nature; a hero capable of surviving in the natural world, but never fully becoming a native, an agent of civilization who does not fit in the very civilization he advances. A good example of such a hero in Hollywood films is the cowboy protagonist in westerns, 
who at the end of the story leaves the village he protected and helped to survive. After this brief digression, let us return to Cameron's film.

Cameron's hero is Jake Sully (Sam Worthington), an ex-marine now hired as a mercenary by RDA, the enterprise that wants to extract unobitanium, the precious mineral hidden in the soil of Pandora. According to the site $\mathrm{IMDb}^{10}$ :

\begin{abstract}
Jake was part of the Avatar Program, in which humans remotely control Human/Na'vi hybrids to safely navigate the planet. Jake was originally assigned to gather intel that would help Colonel Quaritch discover the Na'vi weaknesses so he could force them to leave Hometree or destroy it if necessary. This being done so due to the earth beneath Hometree having a significant deposit of Unobtanium; the entire reason for RDA's interest in Pandora. Jake learns the ways of the Na'vi hunters from Neytiri and is eventually accepted into the Omaticaya clan. Soon after he and Neytiri fall in love. Shortly after this the RDA stages it's attack on Hometree, for which Jake seeks revenge. When everything seems lost to the Na'vi, Jake is able to attain Tsahaylu with a Great Leonopteryx, becoming the sixth Toruk Makto. He plays a key role in the final war, as he leads the Na'vi against the RDA offensive. The Na'vi then perform a ceremony in which they ask Eywa to place Jake's mind into his Avatar body permanently.
\end{abstract}

In addition to the obvious similarity between that definition and the description of the American hero as offered above, one can see a change in his role in American mythology: instead of taking part in the "advancement" of his civilization (even if he does not fit), he changes sides to become a real native and -why not?-, a native American. Indeed, as already mentioned, Jake even takes one step further to become the very leader of the natives; a very significant move, as it will be analyzed bellow. But to understand why such a move is so significant, one must how myth narratives are created and what makes them change.

In complex societies myths are narratives that offer an accessible version of the world, simplifying events of social significance. In the process of its creation, the complexity of History is erased and simplified in an ideologically conservative version. According to Slotkin, myths are

\begin{abstract}
(...) stories drawn from a society's history that have acquired through persistent usage the power of symbolizing that society's ideology and of dramatizing its moral consciousness with all the complexities and contradictions that consciousness may contain. Over time, through frequent retellings and deployments as a source of interpretive metaphors, the original mythic story is increasingly conventionalized and abstracted until it is reduced to a deeply encoded and resonant set of symbols, "icons," "keywords," or historical clichés (SLOTKIN, 1998, p. 5).
\end{abstract}

The function of the myth is to present itself as a key to understand the world around each individual. For instance, the myth of Buffalo Bill stresses his story as a great hunter, one of the great conquerors of the West, while erasing the fact that he would kill buffalos with method and fury with no regard to the destruction of a vital source of food and shelter for the Indians. Thus, ideologically, myth always plays a

${ }^{10}$ IMDb, available at <http://www.imdb.com/character/ch0098390/bio>. Accessed on 31/05/2014. 
conservative function, since it eliminates the complexities of History while presenting itself as a stable and safe narrative; in the example of Buffalo Bill, the mythic narrative turns the massacre of Native Americans into a glorious story of the conquering of Nature. So myths are made of significant historical events and after a myth narrative has stabilized only another historical event, which does not fit in the existing mythology can cause a change in its structure.

So when Cameron changes the role of the American hero in his film, he shuffles all symbolic elements, thus confounding the mythic narrative. In conventional mythic narrative, the inadequacy of the American hero in relation to both "civilization" and Nature, expresses the ideological conflict that has marked the history of the United States, a conflict still to be solved at the level of reality. When Jake Sully is transformed into a real Na'vi a series of new contradictions follow so that, at the bottom line, the very discourse of the film favoring Nature and the peoples of the forest is undermined.

It is worth taking a closer look at how that happens. Jake Sully begins his trajectory by following the conventions of the American hero: i) he initially accepts the conventional mission of clearing the way for the coming of "civilization"; ii) still within the conventions, he shows his uneasiness with the values of such a civilization; iii) following the mythic narrative structure, he learns the ways and values of the "primitive people" in order to learn how to defeat them; iv) while coming to know the people he must conquer and destroy, he stops despising them and begins to learn to respect their culture, thus reproducing the central conflict faced by the American hero, who at that point does not belong anymore neither to his culture, nor to that of the natives; he does not belong to any world, anymore. Conventionally, at that point the mythic narrative ends, with the hero concluding his mission and then departing to some kind of limbo, not civilized, nor savage.

That is the moment when Cameron decided to interfere in the conventional structure and try to solve the contradiction: his hero is literally transformed into a Na'vi. At first sight, such a move may seem as an apology not only of the Native Americans, but of all peoples of the forest. However, it is exactly that symbolic move in Avatar that undermines the film's explicit environmentally and politically correct discourse, thus revealing the actual ideology, which supports its whole narrative.

In order to include such a modification, Cameron is forced to destroy the very heroes of the Na'vi. First, Eytukan (Wes Studi), leader of his people and father of Neytiri (Zoe Saldana), the heroine, dies. Next, dies Tsu'Tey (Laz Alonso), main warrior and second in the line of succession. And finally, Mo'at (CCH Pounder), the spiritual female leader, wife of Eytukan and mother of Neytiri, submits herself and spiritual guidance to the leadership of Jake, thus consecrating him as the new spiritual and warrior leader of the Na'vi.

So in his homage to the peoples of the forest, Cameron destroys their main cultural symbols, replacing them by all that the white hero stands for. ${ }^{11}$ And not only

\footnotetext{
${ }^{11}$ One could claim that in A Man Called Horse (1970), by Elliot Silverstein, John Morgan (Richard Harris), a white English aristocrat is captured by Indians to eventually become the tribe's leader. However, the trajectory of the white hero here is much different from that of Jake Sully. After been captured, John Morgan is striped even from his condition of a human being. Thus, in his process of rehumanization he must leave behind all of his western values until finally adopting the customs and world view of his captors. And when he leads his tribe in war it is not against the American army, but
} 
that: in spite of the final transformation of Jake into a Na'vi following a religious ritual of that people, the fact remains that without the creation of his avatar such a possibility wouldn't even exist. In other words, the new leader of Nature is the very last generation technological product of the capitalist society, which "went wrong"! And if one thinks of the fate of the Na'vi, their mythology will now have to incorporate the fact that their very survival depended on the hero and the technology produced by the same civilization that aimed at the exploitation of their land and even their final destruction. So while simulating admiration for the $\mathrm{Na}$ 'vi/native-Americans, what Avatar really does is to reinforce the myth of Manifest Destiny.

The question that arises is why? Why did Mr. Cameron interfere in such a way in the structure of the myth? One might find a clue in the similarity between Cameron's fantasy and that of George W. Bush and his neocons: to invade Iraq while being welcomed as the heroes and saviors of the Iraqi people. It is the Manifest Destiny again, as it "rests on the assumption that nonwhites need the White Messiah to lead their crusades" (BROOKS, 2010). The need to take one step further to reaffirm such a myth suggests that the historical conditions are changing, with a growing international trend to defy and question America's leadership in the world.

Indeed, there is a growing number of pundits, Americans and from other countries, claiming that the power of the US over the world is decaying. For example, Ramzy Baroud wrote in Asia Times online that "US foreign policy is almost entirely crippled. For the Obama administration, it has been a continuous firefighting mission since George W Bush left office." At the same time, Nobel laureate economist Joseph Stiglitz points to the end of the American Dream, observing how inequality has steadily been increasing in the last decades. In his column in The Guardian, he claims that "America likes to think of itself as a land of opportunity, and others view it in much the same light. (...) Nowadays, these numbers show that the American dream is a myth. There is less equality of opportunity in the United Sytates today than there is in Europe - or, indeed, in any advanced industrial country for which there are data" (The price of inequality).

There is much more to be said about the ideological implications in Avatar; only a few more will be briefly mentioned here. For one, no female character escapes the conventional female roles in the patriarchal structure; much to the contrary, when a female character in the film presents male traits, as with the pilot Trudy Chacon (Michelle Rodriguez), she is punished with her death. Another example can be observed in the extreme Manichaean separation of cardboard characters, which are either all good, or all bad, the most extreme case being that of col. Quaritch, who seems to be the personification of hate e racism, serving only to excite hate from the public. And one can also mention Cameron's insurmountable difficulty to decide about the place and role of the scientists lead by Dr. Grace Augustine (Sigourney Weaver), who seem to nourish a great admiration for the Na'vi and for the Nature in Pandora, but whose investigations never go beyond the collection of samples to no clear purpose at all, making it all look like a clumsy attempt to save the scientific and technological discourse as the path to happiness and success. In other words, an attempt to reaffirm the bases of capitalism.

against another tribe, which eliminates any possibility of reading that film as a restatement of the myth of the Manifest Destiny, nor of the Myth of the Frontier. In fact, in that film white civilization is almost erased. 
All that being said, there is no doubt that Avatar has meant a new step in the technological development of film and the audiovisual. Such kind of technical development is not new in Hollywood, if one thinks of the introduction of sound, color, and so on. Sure enough such developments have always contributed for the seduction of other audiences for the American Dream, based on individual action and material success.

That doesn't mean that one should dismiss Cameron's film: it is useless to condemn new technologies; it is only a matter of not being naïve about their use. And, after all, Avatar is really a beautiful movie.

\section{REFERÊNCIAS}

BAROUD, Ramzy. Asia Times online. Available at <http://www.atimes.com/atimes/World/WOR-01070414.html $>$. Accessed on 31/05/2014.

BROOKS, David. "The Messiah Complex". The New York Times (2010). Available at $<$ http://www.nytimes.com/2010/01/08/opinion/08brooks.html?_r=0>. Accessed on 31/05/2014.

DEBORD, Guy. A sociedade do espetáculo. Rio de Janeiro: Contraponto Editora, 1997.

HABERMAS, Jürgen. "Modernity: An Incomplete Project". In Hal Foster, ed. Postmodern Culture. London and Sydney: Pluto Press, 1985, pp. 3-15.

STIGLITZ, Joseph. The Guardian. Available at

$<$ http://www.theguardian.com/business/2012/jun/05/price-of-inequality-united-states $>$. Accessed on 31/05/2014.

LÉVI-STRAUSS.Tristes Trópicos. Wilson Martins (trans.). São Paulo: Editora Anhembi, 1957.

LYOTARD, Jean-François. The Postmodern Condition: A Report on Knowledge. Manchester U Press, 1986. . O Pós-Moderno Explicado às Crianças. Publicações Dom Quixote Lisboa: 1993, 2nd ed.

SLOTKIN, Richard. Gunfighter Nation: The Myth of the Frontier in Twentieth-Century America. University of Oklahoma Press: Norman, 1998 (1st. ed. 1992).

.The Fatal Environment: The Myth of the Frontier in the Age of Industrialization, 1800-1890.

University of Oklahoma Press: Norman, 1998 (1st ed. 1985).

.Regeneration Through Violence: The Mythology of the American Frontier, 1600-1860. Harper

Perennial: 1996 (1st ed.1973).

WOOD, Robin. “Ideology, Genre, Auteur.” Film Comment, Jan-Feb pp 46-51, 1997.

Recebido em: 13/06/2014. Aprovado em 15/06/2014.

Título: Avatar como sintoma: a narrativa mitológica de Hollywood e crise

Author: Fernando Simão Vugman

Resumo: O presente ensaio faz uma análise do filme Avatar (2009), de James Cameron sob o ponto de vista das grandes narrativas mitológicas estadunidenses. Com foco na dramatização do mito da Fronteira e do Destino Manifesto, além do sonho americano, seu roteiro, mise-en-scène e personagens são discutidos como uma quebra nas convenções mitológicas e hollywoodianas. Esta quebra com as convenções do mito é compreendida como sintoma de uma grave crise atualmente vivida pela sociedade estadunidense, refletindo a necessidade de repensar o presente do país e suas alternativas para o futuro.

Palavras-chave: Mitologia Americana. Crise Americana. Cinema e tecnologia. Hollywood. Avatar. 